\title{
PRIHODNOST SISTEMA KARIERNE POTI ČASTNIKA V SLOVENSKI VOJSKI
}

\section{FUTURE OF THE OFFICER CAREER DEVELOPMENT SYSTEM IN THE SLOVENIAN ARMED FORCES}

Povzetek V članku opisujemo prihodnost sistema karierne poti častnika v Slovenski vojski, in sicer za prvih deset let njegove kariere. Naš glavni namen je razviti predlagani sistem častniške karierne poti za Slovensko vojsko, ki bo zagotavljal določeno stopnjo predvidljivosti v častnikovi karieri in vključeval opredeljive kompetence ter razvoj konkurenčnega okolja za njegovo napredovanje. Osredotoča se na določanje ustreznih orodij za vse štiri funkcije upravljanja kadrov, ki so izvedljive in sprejemljive znotraj omejitev, ki jih postavlja zakonodaja.

V članku je razložen sistem karierne poti častnika na podlagi štirih kadrovskih funkcij, ki so opredeljene kot zaposlitev, razvoj, napredovanje in prehod. Slovenska vojska na podlagi transformacije reorganizira svoje enote $\mathrm{v}$ polkovni sistem, v katerem imajo poveljniki čet čin majorja. To je eden izmed razlogov, zakaj v članku obravnavamo tudi sistem karierne poti častnika v britanski vojski, ki bi bil v nekaterih pogledih lahko primeren za novo strukturo Slovenske vojske.

Poleg obravnave predlaganega sistema karierne poti za častnika so v članku navedeni tudi nekateri novi koncepti upravljanja kadrov, kot so izboljšan program zaposlovanja, razvrščanje $\mathrm{v}$ skupine po letih, odbori častnikov in nov sistem ocenjevanja. Vsi ti koncepti omogočajo v predlaganem sistemu častniške karierne poti uvedbo centraliziranega upravljanja kadrov ter zagotovitev pregledne in predvidljive karierne poti, ki temelji na sposobnostih posameznika.

Ključne Slovenska vojska, sistem karierne poti častnika, funkcije upravljanja kadrov: besede zaposlitev, razvoj, napredovanje in prehod, razvrščanje v skupine po letih.

Abstract The article describes the future of the Officer Career Development (OCD) system in the Slovenian Armed Forces (SAF) for the first ten years of an officer's career. The main purpose of the article is to develop a proposed OCD system for the 
SAF which will provide a certain level of predictability in an officer's career and include identifiable competencies as well as develop a competitive environment for officer promotion. The article focuses on determining appropriate tools for all four functions of the personnel management, which are feasible and acceptable under the constraints provided by the legislation.

The article defines the OCD system through four personnel functions defined as employment, development, promotion and transition. The SAF, through the transformation process, is reorganizing its units into a regimental system with company commanders being in the rank of major. This is one of the reasons the article also looks at the British Army (BA) OCD system which, in certain areas, could be applicable to the new structure of the SAF.

The article discusses the proposed OCD system and introduces several new concepts in personnel management such as: improved employment programme, year group rankings, officer's boards and new evaluation system. All these new concepts allow the proposed OCD system to introduce centralized execution of personnel management and provide a transparent and predictable career path, based on competencies of an individual.

Key words Slovenian Armed Forces, Officer Career Development system, functions of personnel management: employment, development, promotion and transition, year group ranking.

Introduction Since the topic of the article is based on the basic premises of the personnel management system, particularly the current Officer Career Development (OCD) system in the Slovenian Armed Forces (SAF) and the British Army (BA), this article focuses on the changes in the Officer Career Development (OCD) system that the SAF should adopt for the first ten years of an officer's career in order to meet its future challenges.

The most recent transformation of the SAF started in 2012, its reorganization bringing about several changes in the structure of the organization and consequently affecting the current OCD system. The purpose of the transformation was to enhance the organizational effectiveness and rationalize the SAF structure (Government of the Republic of Slovenia, 2013). The proposed OCD system looks at these changes through the new formations of units, changes in the Military Education and Training (MET) requirements for different assignments, and changes in ranks for certain assignments.

The reorganization process should be completed by 2018 and will introduce the new structure of the SAF. Previously, the SAF structure was comprised of the General Staff of the SAF (GS SAF), with Force Command and TRADOC as first subordinate commands. The Force command was divided into brigades which 
were further divided into battalions. The new SAF structure keeps the GS SAF at the top, together with the Centre for MET and the Combined Operations Centre. Because the Force Command and TRADOC were dissolved in the process of the transformation, the units, which are divided into manoeuvre and logistics brigades, are now directly subordinate to the GS SAF. Lower echelons are manoeuvre and support regiments, as well as some independent regiments (Government of the Republic of Slovenia, 2013). For the scope of this article, changes in the OCD system are depicted through the structure and assignments within the infantry brigades and regiments, where the bulk of an officer's career in the first ten years will take place.

Assignments in the regimental staff are planned to be executed in the ranks of 1LT, CPT and MAJ. MAJs are Section Leader (SL) in the S3 and S4, other Staff SLs are CPTs. The Chief of Staff (COS) in a Regiment is also a MAJ, while the regimental $\mathrm{XO}$ is an LTC and the regimental commander a COL. Regiments are battalion-sized formations with company commanders (CO CDR) being majors, their executive officers (XO) CPTs, and platoon leaders (PLT LDR) 2 and 1LTs.

Other significant changes included in this proposed OCD system are the MET requirements for the positions executed in the ranks of CPT and MAJ. The previous MET requirements for assignments in the rank of CPT remain the same; however, the requirements for the rank of MAJ have changed and are depicted in the proposed OCD system. Therefore, the proposed OCD system focuses on the Basic Military Education and Training (BMET), the Staff Course (SC), and different forms of Complementary Training Programmes (CTP).

Similarities with the OCD system in the BA are quite obvious in terms of the regimental structure and developing an officer to the rank of major, at which point they can assume the position of a company commander. Although the BA's employment system is somewhat different from the SAF, the subsequent training, assignments and competencies are applicable to the new structure of the SAF, and are depicted in the proposed OCD system. However, the equivalent of CTP in the BA is focused more on the continuous development of an officer, which the proposed OCD system takes into account.

\section{RESEARCH METHODOLOGY}

The analysis of different laws governing the Slovenian Defence System and its personnel management calls for a comparative case study. Literature review determined some of the specifics of the current OCD system as well as the environment for the SAF officer corps. This environment changed drastically after the Republic of Slovenia joined NATO and the EU, bringing new challenges for the military in terms of its roles and functions. It is these new challenges that drive the decisions in the competency-based OCD system. 
Previous attempts at describing the OCD system in the SAF were generally focused on career models, describing how the SAF develops and promotes officers through the personnel management functions. The existing career models tried to encompass the legal framework of the promotion system which consists of assignment to positions, years in the service and the Officer Evaluation Report (OER), as well as the possible positions to which an officer should be assigned within the three career pillars. All of those career models, along with a comparison to the BA system, help the author in proposing changes to the OCD system.

Identifying aspects of the BA OCD system helps describe the important aspects of the retention policy as well as the career path of individual officers. The proposed changes in the existing OCD system will be closely connected to the strategy of the SAF and the competencies required for the achievement of this strategy, which, in turn, will be closely connected to all four personnel functions of the proposed OCD system.

Although this article focuses its research on the first ten years of service, the proposed OCD system will encompass all four personnel functions, trying to show the need for transition for a certain percentage of individuals at the end of the contract term. Therefore, introducing the transition function in the first ten years of an officer's career, together with the separation process, is crucial in building a competent officer corps as well as maintaining the necessary pyramid structure of the SAF.

\section{DEFINITIONS}

Officer. A person who holds a position of authority or command in the military (Merriam-Webster Dictionary, 2013). In the SAF, an officer has university education and has finished the Officer Candidate School. The ranks of an officer in SAF are: second lieutenant, first lieutenant, captain, major, lieutenant colonel, colonel and brigadier (Defence Act, 2004).

Officer Corps. "This is the body of commissioned officers imbued with a unique self-concept defined by the following four identities: warrior, member of profession, servant of country, leader of character." (Matthews and Snider, 2005: 9). The SAF Officer Corps is the most professional part of military profession in the SAF forces (Jelušič, 1997).

Career Development System. Is a process of balancing an employee's career needs and an employer's labour needs. The organizational tools and subsystems of the CD system, used by an employer, are recruitment, the system of promotion and motivation, determination and evaluation of competencies, and training and evaluation (Štefanic, 2010). The OCD is a career development system specifically designed for officers. 
Competencies. Competencies are defined as the activation and connection of individual knowledge, capabilities, motivation, self-awareness and values, allowing an individual to perform his or her duties and solve problems in unknown and diverse environments (Kohont and Naglič, 2006). Competencies provide military leaders with a clear and consistent way for conveying their expectations. Military leaders serve to lead others, to improve the environment, to develop themselves, others and the profession as a whole, and to achieve the organizational goals (ADP 6-22, Mission Command, 2012).

Career path. Is a variable line in an individual's progression through different positions during their employment in the armed forces. It is connected with the ability of an individual to be promoted, assigned to other positions within the same pay grade, or degraded. The career path in the SAF presents possible positions or reassignments for each individual.

Key development positions. These are deemed fundamental to the development of an officer in his or her core branch or functional area competencies, or deemed critical by the senior military leadership to provide experience across the military's strategic mission (DA Pam 600-3, Commissioned Officer Professional Development and Career Management, 2010).

Retention policy. Represents a set of rules and standards, set by an organization, which must be achieved by individuals who want to remain in the organization. It provides the tools to define requirements to those individuals who are already in an organization in order to prolong their employment, or serve as criteria to reduce the members of an organization through the separation process, as part of the transition function.

\section{PROPOSED OCD SYSTEM IN THE SAF}

One of the author's professors at the Command and General Staff College (CGCS) said to always begin with an end goal in mind, otherwise each and every road will do. That being said, this article is based on some of the challenges the SAF will face in the future, as well as on constraints placed on the OCD system by the legislation governing the SAF and its members. The proposed OCD system tries to encompass these challenges and constraints, and include them in the OCD system through a competencies-based approach. Competencies are understood as a means used by the senior SAF leadership to direct the training and education process of its personnel in order to achieve the SAF's strategic goals.

Failing to communicate those needs to the personnel management of an organization (Tomažič, 2013) eventually leads to a situation in which the senior leadership cannot achieve the strategic goals through the availability of trained and competent officers. A clear set of competencies is very important in the early stages of an officer's career and aids the SAF in the building of its officer corps by clearly communicating the 
expected competencies to an individual and the society. The proposed OCD system is based on competencies and encompasses all four personnel management functions of employment, development, promotion and transition.

The first challenge of the SAF is determined by the current fiscal constraints which might have long term-effects on the organization, while forcing the SAF to prove its relevance to the people of the Republic of Slovenia. The second challenge for the SAF is its growing involvement in multinational HQs within NATO and the European Union. Other challenges are posed by deployments in various UN and NATO-led operations, and by being heavily involved in supporting the civil authorities in times of natural disasters and other emergencies. The Slovenian Armed Forces played a crucial role in the recent sleet that crippled almost half of the country in February 2014. Supporting the national and local natural disaster relief agencies and using its bilateral relations with other armed forces has led to more efficient support to the affected population. The SAF's relationship with partner countries has led to additional generators from the $173^{\text {rd }}$ IBCT from Vicenza being delivered to the Postojna area which was most affected by sleet.

The proposed competencies-based OCD system looks at these challenges and determines the competencies that individual officers must have in order to lead the SAF in the future. Being able to communicate both in the domestic and international environment, using foreign languages, and having 'intellectual interoperability' with peers within the NATO and EU structures are some of the competencies the proposed OCD system looks at. Being able to operate in a fiscally constrained environment would force an officer at the tactical level to show a high level of commitment, motivation and initiative to find a way to mitigate these constrains in the training and operational environments.

\subsection{Concepts supporting the proposed OCD system in the SAF}

To support the development of those competencies and provide a transparent OCD system, the proposed OCD system introduces several new concepts: improved emplyoment programme, evaluation report, key development positions, and year group ranking of officers. These concepts are the foundation for the proposed OCD system and have to be adopted in conjunction with changing the personnel management system.

The improved employment programme is one of the new concepts the proposed OCD system would introduce into the SAF. It upgrades the existing scholarship system with the purpose of identifying the competencies needed to accept an individual in the SAF during his or her under-graduate years.

Another new concept is the comprehensive evaluation concept which is no longer based solely on an individual's OER, but includes soft competencies and competencies not included in the OER, as well as the recommendation from a superior officer. The OER, soft competencies and superior's recommendation are combined in the 
Officer Evaluation Package (OEP) which presents a more centralized evaluation management system intended to support all three functions of personnel management after an individual is accepted in the SAF.

The proposed evaluation process represents the basis for developing and promoting officers in the SAF. A weighted method of three different parts of the OEP gives $40 \%$ weight of the OEP to the commander's recommendation and $30 \%$ to soft competencies and the OER. The OEP is measured by a scale of one to five, and follows the same scale as the OER in order to avoid confusion.

The third new concept is the introduction of key development (KD) positions with the proposed OCD system emphasizing certain positions that must be held by an individual in order to assume leadership positions. KD positions more or less contribute to the soft competencies of an individual and are part of the OEP.

The OEP is therefore used to support the rankings for assigning an individual a KD position, provide information for the ranking list of an individual for other assignments and promotions, as well as to enrol an individual in the Advance Military Education and Training (AMET) and complementary training programmes (CTP) in Slovenia and abroad. The OEP will also be used in determining a retention policy on the basis of which the individuals who do not comply with the prescribed standards could be excluded after the first two or ten years of their service in the SAF, as is outlined in the 2013 and 2014 Guidance.

The last new concept of the proposed OCD system is the ranking of officers within their year group, where they are ranked bellow, within, or above the 'zone'. The article discusses all these new concepts in detail bellow.

\subsubsection{Employment of an officer in the SAF}

The SAF entry requirements are defined in the Defence Act (2004) and will not be discussed in detail in this article because the proposed OCD system is based on the current legislative framework. Future demands for officers in the SAF call for the employment of approximately 35 individuals per year. The number is a rough estimate based on the calculation of the current needs which call for the employment of about 15 officers per year, and takes into account the need for increased numbers due to the separation process as well as the need for officers in the reserve component. The separation process will be discussed in detail in the last of the four personnel management functions.

One of the shortfalls of the existing system is the low level of commitment that the students in the scholarship programme are required to show during the study. This has recently been changed with the organization of "summer camps" where students are able to practice certain individual and squad-level skills and procedures. However, the summer camp was not recognized as a formal completion of any of the forms of Core Level Training (CLT) prior to 2008, when the Minister of Defence adopted the 
Regulation for Scholarship in the SAF, and is even today open to all interested students regardless of their status in the scholarship programme. In other words, it represents the only event in which students are evaluated and trained; however, having other students present on a voluntary basis does not help the evaluation and selection process.

Military summer camps are an excellent way of promoting the military profession among the student population in Slovenian universities, but have failed to meet the expectations of providing a proper assessment of the scholarship programme members and of recruiting new individuals to the armed forces. Not receiving any formal recognition after the completion of camps has led the senior leadership into making changes to the entire enrolment system that the proposed OCD system in this paper takes into account.

Enrolment in the proposed OCD system is based on the needs of the SAF for new officers. The proposed enrolment process also takes into account the organizational changes in the SAF after the completion of transformation in 2018 and the ratio between officers, non-commissioned officers (NCO) and privates, which, at the end of the transformation process, should be 1:2:4 (Midterm Defence Programme of the Republic of Slovenia, 2013).

Igor Kotnik (2008), the current political advisor to the Chief of the GS SAF, in his article "A Modern Officer of the Slovenian Armed Forces: Their Characteristics and Formation", highly recommends the format of the US ROTC programme. In his opinion, this programme provides the most cost-efficient way to obtain new individuals for the officer corps in the SAF. The existing OCD system already has in place a scholarship programme which gives scholarships to students of different universities in Slovenia and sends certain individuals to academies abroad.

The enrolment programme based on the Reserve Officer Training Corps (ROTC) in the US military should be adopted to allow the SAF to monitor an individual through all four years of his or her under-graduate education. The Defence Act and Regulation for Scholarship in the SAF require, among other things, the following in order to enter and finish the scholarship programme:

- An individual must complete medical and physical screening prior to entering the programme;

- An individual must complete the Core Level Training (CLT) during his or her four years of study (Regulation for Scholarship in the SAF, 2008).

The proposed OCD system recommends changes to the existing regulations, further regulates the scholarship programme and introduces additional requirements:

- An individual must finish school in the required academic years; the only exemption would be for medical causes, but an individual must still be medically fit for military duty upon graduation;

- An individual must be actively engaged in the activities of the SAF through the civil-military events offered at university; 
- An individual must complete medical and physical fitness examinations every two years.

These changes might help in implementing the already existing postulates for introducing the ROTC programme into the SAF in the framework of the Doctrine of Training and Education. The improved enrolment programme in the proposed OCD system should provide up to 90 percent of future officers, while the other ten percent should be divided among the applicants from the existing SAF structure and specialists such as doctors, legal personnel, clergy and others. The paper omits details on these specialists due to the special consideration for this personnel and very low numbers of these individuals on a yearly basis.

Selection for the Officer Candidate School (OCS) in the proposed OCD is very similar to the one the BA has and serves as an additional selection process for the SAF for accepting an individual with the necessary competencies for becoming an officer of the SAF. The selection is also necessary for the prior enlisted personnel chosen by the SAF to apply for the OCS. The enlisted personnel should possess the same level of competencies but are not sent to the CLT, as they have already finished a CLT upon their employment in the SAF. Similar can be observed in the British Army OCD system within the Late Entry (LE) programme, where serving soldiers are eligible to apply for an LE commission upon completion of nine years of reckonable service. The one big difference is that all LE officers are commissioned as captains (Offices Career Development Handbook, 2005). While the current selection process for the OCS recognizes certain entry-level skills, the proposed OCD recommends basic competencies of an individual entering the OCS. The proposed OCD system recommends a similar technique for measuring these competencies as the BA selection process, using a form of the Army Officer Selection Board. These competencies should, at minimum, be:

- Physical fitness;

- Ability to effectively communicate in Slovenian and at least one of the official NATO languages;

- Motivation and sense of responsibility;

- Reliability and initiative;

- Living by the SAF values. ${ }^{1}$

The proposed programme should also allow the SAF to communicate expected competencies to future members of the SAF Officer Corps and the RS society, with the intent of building confidence in its military. The programme should also enforce high standards for future officer corps, having oversight of the level of commitment to the profession of arms as well as flexibility to cope with a changing environment which could demand different profiles of officers. The next step of the proposed OCD system deals with the development and promotion of an officer from the early stages of his or her career all the way to the ten-year mark.

1 For the definition of each competency look at Appendix: Table of proposed competencies. 


\subsubsection{Development and promotion of an officer in the SAF}

The proposed OCD system develops officers according to the Doctrine of Training and Education (TED). The development starts with the selection process as the entry requirement for the Officers Candidate School (OCS), and continues with the OCS and Military Occupational Specialty (MOS) schools as the second part of the Basic Military Education and Training (BMET). Officer's professional development after the BMET is continued with the complementary training programmes (CTP) and the Staff Course as part of the Advance Military Education and Training (AMET) and one of the prerequisites for the rank of captain.

During the OCS the candidates are continuously trained and evaluated through the competencies acquired before the OCS; moreover, they develop new competencies which are needed for commissioning as a 2LT. Those additional competencies for the first two officer's ranks include:

- Emotional intelligence;

- Powers of communication in the Slovenian language;

- Subordinate development;

- Professional effectiveness;

- Tactical proficiency;

- Communication in an official NATO language;

- Leadership;

- Management of resources. ${ }^{2}$

After completion of the OCS, the SAF commissions an individual into the rank of 2LT and provides MOS training during which an officer obtains competencies for his or her branch and future assignments. The officer is still under constant evaluation, which gives the SAF ability to manage the structure of the officer corps in the early stages of an officer's career.

The next step of the development of an individual is the CTPs which are intended to give an individual additional competencies to execute specific assignments. While the current OCD system recognizes two parts of the CTP and is focused on training and educating an individual for specific assignments, the proposed OCD system looks at the BA and recommends the following applicable programmes from the BA system for the SAF CTP.

The SAF, like the BA, should develop its CTP as a continuing professional development from the rank of captain to major and above. The CTP system is developed to provide individuals with short resident courses at designated schools or to distribute course material to individuals while working in units and then testing their knowledge through various exams. The BA's CTP is focused on developing additional leadership skills, creative and critical skills such as writing, and preparing individuals for future AMET courses.

2 For the definition of each competency look at Appendix: Table of proposed competencies. 
The current TED (Pešec, 2013) in the SAF recognizes the next level in developing an officer through the AMET. The scope of this article looks at the first part of the AMET, which is the Staff Course (SC). The proposed OCD system introduces several additional requirements as well as the entry-level exam for the SC, which will provide an additional tool for the OEP and identify the competencies needed to advance to the SC.

The selection process for the SC should begin in the third and fourth year of an officer's career, with the OEP for both of those years providing the tools for ranking the year group. The officers with the highest OEP in the year group represent the 'below zone' for their year group and are legible to apply for the SC in their fifth year with the 'in-the-zone group' of the previous year and the 'above the zone' group from previous two years. The entry-level exams play a crucial role in identifying the qualification to enter the SC from all three year groups and serve as an additional selection tool for the SAF to use in determining the retention policy.

The last part of developing an officer within the proposed OCD system is the Company Commander Course as part of the CTP. This should be a week-long course executed in a designated institution after completing the company command selection and within six months of assuming command. A company commander, in relatively small armed forces as the SAF, with a prevalent deployment policy, which is based mostly on company-sized units being deployed, is a very important assignment which can have strategic implications for the Republic of Slovenia. Therefore, the Company Commander Course should build on the legal, financial and administrative as well as leadership and tactical competencies needed to command a company. Moreover, it should provide an individual with the latest overview of the National Defence Strategy and the Midterm Defence Programme in order to obtain the latest strategic guidance for the SAF.

The CTP and SC are oriented to prepare an officer to assume assignments such as a company executive officer (CO XO), regimental staff officer (Reg. Staff), regimental section leader (Reg. Sect. LDR), Brigade Staff (BDE Staff), instructor in Military Education and Training (MET) institutions, regimental XO or Chief of Staff, or Section S3 and S4 leader (Reg/COS/S3/S4), General Staff of the SAF position (GS $\mathrm{SAF}$ ), company commander (CO CDR), and others. The competencies for the ranks of captain and major are listed as general competencies, commander competencies and staff pillar competencies. The proposed OCD system recommends that an officer possess the following competencies to meet the demands of those assignments:

- General competencies:

- Emotional intelligence;

- Powers of communication (able to publish articles in SAF magazines);

- Motivation;

- Responsibility;

- Subordinate development;

- Courage; 
- Reliability;

- Professional effectiveness;

- Initiative;

- Tactical proficiency;

- Communication in at least one of the official NATO languages.

- Commander's pillar:

- Embrace ambiguity;

- Leadership;

- Accept prudent risk.

- Staff pillar:

- Analytical skills;

- Interdisciplinary;

- Accuracy;

- MDMP proficiency;

- Organizational skills;

- Mission Command systems proficiency. ${ }^{3}$

The current promotion system in the SAF depends on individual assignments, years of service and a person's OER. The proposed OCD system builds on the current system and recommends the concept of year groups, as already presented.

The year group, based on the OEP, provides a transparent and competitive model that provides a satisfying level of predictability in an officer's career. This concept would allow the ranking of officers within their respective year groups. The concept will therefore eliminate confusion and lack of transparency in certain personnel management actions. Promotion and development as well as separation will be executed among the same year group at once, allowing for the competiveness of officers among themselves.

The proposed OCD system also introduces the KD positions for the most demanding and prestigious assignments in an officer's career. The proposed 2014 Guidance of the Ministry of Defence for career management in the SAF recommends giving advantage to assignments to leadership positions if an individual held the identified KD positions. The proposed OCD system identifies the KD positions prior to company command, regimental and brigade section leader or regimental COS. For assignment to company command, an individual should hold the following KD positions:

- PLT LDR in their branch;

- Instructor in MET or Company XO;

- Being deployed as part of a regiment.

For assignments to regimental or brigade section leader (S3, S4) or Regimental COS:

- Company commander;

- BDE Staff or Regimental S3, S4.

3 For the definition of each competency look at Appendix: Table of proposed competencies. 
Table 1:

Proposed career system in the new OCD system

\begin{tabular}{|c|c|c|c|c|c|c|}
\hline RANK & \multicolumn{4}{|l|}{ POSITIONS } & \multirow{2}{*}{$\begin{array}{l}\text { SELECTION } \\
\text { PERIOD }\end{array}$} & \multirow{2}{*}{$\begin{array}{l}\text { YRS IN } \\
\text { SERVICE } \\
\text { 10YRS }\end{array}$} \\
\hline $\begin{array}{l}\text { MAJ/ } \\
\text { CPT }\end{array}$ & $\begin{array}{l}\text { MAJ: } \\
\text { CO CDR, MET, } \\
\text { Reg. XO/COS/ } \\
\text { S3/S4, GS SAF, } \\
\text { BDE Staff }\end{array}$ & $\begin{array}{l}\text { CPT on MAJ: } \\
\text { MET, Reg. XO/ } \\
\text { COS/S3, GS } \\
\text { SAF, BDE Staff }\end{array}$ & $\begin{array}{l}\text { CPT: } \\
\text { Reg. sect. LDR, } \\
\text { BDE Staff }\end{array}$ & $\begin{array}{l}\text { Separation } \\
\text { process at the } \\
\text { end of } 10 Y R S \\
\text { mark }\end{array}$ & & \\
\hline $\begin{array}{l}\text { CPT/ } \\
1 \mathrm{LT}\end{array}$ & $\begin{array}{l}\text { CPT on MAJ: } \\
\text { MET, Reg. XO/ } \\
\text { CoS/S3/S4, GS } \\
\text { SAF, BDE Staff }\end{array}$ & $\begin{array}{l}\text { CPT on MAJ: } \\
\text { MET, Reg. XO/ } \\
\text { COS/S3/S4, GS } \\
\text { SAF, BDE Staff }\end{array}$ & $\begin{array}{l}\text { 1LT on CPT: } \\
\text { CO XO, Reg. } \\
\text { staff, BDE Staff: } \\
\text { 1/3 Separation }\end{array}$ & $\begin{array}{l}\text { 1LT: } \\
\text { Reg. Staff: } \\
\text { Separation }\end{array}$ & \multirow{2}{*}{$\begin{array}{l}2^{\text {nd }} \text { Selection } \\
\text { for the } \\
\text { zone and } \\
\text { retention }\end{array}$} & 9YRS \\
\hline $\begin{array}{l}\text { CPT/ } \\
1 \mathrm{LT}\end{array}$ & $\begin{array}{l}\text { CPT on MAJ: } \\
\text { MET, Reg. XO/ } \\
\text { COS/S3, GS } \\
\text { SAF, BDE Staff }\end{array}$ & $\begin{array}{l}\text { CPT: } \\
\text { CO XO, Reg. } \\
\text { sect. LDR, BDE } \\
\text { Staff, MET }\end{array}$ & $\begin{array}{l}\text { 1LT on CAPT: } \\
\text { CO XO, Reg. } \\
\text { staff, BDE Staff }\end{array}$ & $\begin{array}{l}\text { 1LT: } \\
\text { Reg. Staff }\end{array}$ & & 8YRS \\
\hline $\begin{array}{l}\text { CPT/ } \\
1 \mathrm{LT}\end{array}$ & $\begin{array}{l}\text { CPT: } \\
\text { CO XO, Reg. } \\
\text { sect. LDR, BDE } \\
\text { Staff, MET }\end{array}$ & $\begin{array}{l}\text { 1LT on CPT: } \\
\text { CO XO, Reg. } \\
\text { sect. LDR, BDE } \\
\text { Staff }\end{array}$ & $\begin{array}{l}\text { AZ: 1LT on } \\
\text { CAPT: } \\
\text { Staff Course }\end{array}$ & $\begin{array}{l}\text { 1LT: } \\
\text { Reg. Staff }\end{array}$ & & 7YRS \\
\hline $1 \mathrm{LT}$ & $\begin{array}{l}\text { 1LT on CPT: } \\
\text { CO XO, Reg. } \\
\text { sect. LDR, BDE } \\
\text { Staff }\end{array}$ & $\begin{array}{l}\text { Z: 1LT on CPT: } \\
\text { Staff Course }\end{array}$ & $\begin{array}{l}\text { 1LT: } \\
\text { PLT LDR, Reg. } \\
\text { Staff }\end{array}$ & $\begin{array}{l}\text { 1LT: } \\
\text { Reg. Staff }\end{array}$ & & 6YRS \\
\hline 2/1LT & $\begin{array}{l}\text { BZ: 1LT on } \\
\text { CAPT: } \\
\text { Staff Course }\end{array}$ & $\begin{array}{l}\text { 1LT: } \\
\text { PLT LDR, Reg. } \\
\text { Staff }\end{array}$ & $\begin{array}{l}\text { 2LT on 1LT: } \\
\text { Reg. Staff }\end{array}$ & $\begin{array}{l}\text { Separation } \\
\text { process at the } \\
\text { end of } 5 \text { YRS } \\
\text { mark }\end{array}$ & & $5 Y R S$ \\
\hline 2/1LT & $\begin{array}{l}\text { 1LT: } \\
\text { PLT LDR, Reg. } \\
\text { Staff }\end{array}$ & $\begin{array}{l}\text { 1LT } \\
\text { PLT LDR, Reg. } \\
\text { Staff }\end{array}$ & $\begin{array}{l}\text { 2LT on 1LT: } \\
\text { Reg. Staff }\end{array}$ & $\begin{array}{l}\text { 2LT on 1LT: } \\
\text { Reg. Staff }\end{array}$ & $1^{\text {st }}$ Selection & 4YRS \\
\hline $2 \mathrm{LT}$ & $\begin{array}{l}\text { *2LT on 1LT: } \\
\text { PLT LDR, Reg. } \\
\text { Staff }\end{array}$ & $\begin{array}{l}\text { 2LT on 1LT: } \\
\text { PLT LDR, Reg. } \\
\text { Staff }\end{array}$ & $\begin{array}{l}\text { 2LT: } \\
\text { PLT LDR }\end{array}$ & $\begin{array}{l}\text { 2LT: } \\
\text { PLT LDR }\end{array}$ & zone** & 3YRS \\
\hline 2LT & \multicolumn{5}{|l|}{ PLT LDR } & 2YRS \\
\hline$-2 \mathrm{LT}$ & \multicolumn{5}{|l|}{ OCS / MOS } & $1 Y R$ \\
\hline
\end{tabular}

* Meaning an individual is assigned to a position of higher rank to the one currently held (in this case, a $2^{\text {nd }} L T$ is assigned to a position for the rank of $1 L T)$.

** Selection is based on the OEP in the $3^{\text {rd }}$ and $4^{\text {th }}$ year and is used to determine individuals above the zone (AZ), in-the-zone ( $\mathrm{Z})$ and bellow the zone (BZ) of their year group. 
The promotion system is based on promotion in assignments and is depicted in the Table: Proposed Career System. New assignments in the Table are depicted in the column showing an individual with a lower rank occupying a higher-rank position for a certain amount of years, based on the existing legislation. The proposed OCD system clearly identifies the years in an officer's career when he can expect promotion to a new assignment with a higher rank and years when he can expect promotion in rank if he achieves a proper OEP rating.

In addition to showing the proposed career system in the SAF as part of the proposed OCD system, the Table below focuses on the structure of both infantry brigades of the SAF, which represent the bulk of officer positions in the first ten years of their careers. The Table includes officers in both career pillars and intentionally omits the specialist pillar. This Table intentionally does not present all possible assignments for officers in the navy and air branches, and omits certain positions in the sustainment branch. A comprehensive approach to the personnel management of the SAF should depict positions equivalent to the ones represented in the Table for other branches.

The first and second selection time periods for the year groups are depicted in the selection period column of the table and present the critical years used by the SAF for its transition policy as well as the assigning of officers to the MET or new assignments.

\subsubsection{Transition of an officer in the SAF}

Transition of an officer is the last personnel function through which the proposed OCD system defines the retention and separation actions. The proposed OCD system recognizes all termination criteria depicted in different legislative documents. The focus of the transition phase in the proposed OCD system follows the transparency principle and defines the criteria for the separation or retention. The intent is to clearly depict the milestones in an officer's career in the first ten years, when an officer can expect those actions to occur.

This article defines those milestones and criteria in the Table: Proposed career system. In this Table, the proposed OCD system depicts the first separation process after five years and the second after ten years of an officer's career. Once again, the OEP is the base for determining whether or not an officer is eligible to sign another contract. In order to support these milestones, the proposed OCD system includes two selection periods. The first milestone is proposed at the third and fourth year mark of an officer's career, and the second one at the eighth and ninth year mark. Both selection periods are also used for development and promotion functions. As shown in the Table, individuals with the OEP of two or less in the third and fourth year of their career are to be separated after five years and are not planned for any higher assignments or future MET. The same goes for the second selection period where individuals with the OEP of two or less are considered for separation and not planned for higher assignments or future MET. Those individuals stay in the military according to their contract until their fifth or tenth year of service, using the last year of their career for the separation process. 
Although the Table shows that the separation occurs for individuals with the OEP of two or one, the proposed OCD system recognizes the ability of the SAF to decide to retain more individuals or increase the number of separations depending on the SAF needs, which it should communicate well in advance.

At the five or ten-year mark, the SAF, under the current legislation, is not obliged to pay any severance to the individual who is separated from the military. The retention policy depends on the manning needs of the SAF, where the proposed OCD system recommends commencing the process at least one year before the contract can be renewed or terminated. As part of the separation process, the SAF should provide additional training for an individual to be qualified for another job, or start procedures to employ an individual as a civilian in the Ministry of Defence or other equivalent assignments within the government.

The latter is especially important for the individuals who do not decide to stay in the military after five or ten years, but their service was exemplary. The proposed OCD system recommends developing mechanisms to provide those individuals assignments in equivalent positions within the government structure if they wish to do so. Providing those assignments to individuals within the government system should minimize the employments of new civil servants, while maintaining competencies within the defence or a broader government system.

\subsection{Summary}

The proposed OCD system provides the foundation for developing the personnel management policy and processes within the SAF. A clear evaluation method through the OEP should provide the personnel management division with the right tools for all four discussed personnel management functions. A combination of the OEP and the concept of year group division, and using this in assigning individuals to MET and new assignments, as well as in developing the retention or separation policy should help build transparency in the system.

The proposed OCD system enables the establishment of a more centralized personnel management system and reduces administrative work at lower echelons. It would create bottom-up reporting through the OEP and top-down management. In addition, the personnel management division should appoint a department to manage its officers in accordance with the needs of the SAF. The directives within the SAF should establish this element to coordinate officers' careers within different branches, as seen in the BA, preside over the Officers' Boards and use the OEP when executing different personnel actions.

Central execution of personnel management and demanding selection processes at all levels of an officer's career, based on competencies, should provide the basis for a competitive environment in which officers will advance according to their year group and abilities. This would allow the OCD system to introduce a demanding but transparent and predictable system. This system, in which officers could enjoy the 
learning environment and be able to excel solely on the basis of their capabilities, would lead the SAF, as the current Minister of Defence, Roman Jakič, stated in his interview for the national television, towards "a small, well equipped, flexible and professional military.” (Roman Jakič, Interview on the National TV Slovenia, 29 April 2013).

Conclusion The environment in which the SAF is operating today will definitely change in the future. Currently, the SAF has to be able to operate in an international environment as part of the standing headquarters of international organizations or part of internationally led operations in different parts of the world. While being a credible partner in the international environment, the SAF has to conduct its primary task of protecting the sovereignty and integrity of the territory of the RS and proactively engage in other activities of the Slovenian society. The proposed OCD system makes recommendations to help produce such leadership in the SAF that will be able to execute the proposed and required tasks and activities in domestic and international environments in the future.

The Slovenian Armed Forces played a crucial role in the War for Independence in 1991 and remains the most trusted national institution in the Republic of Slovenia (Political Barometer, 2013). This type of trust is (according to the 2012 US Army White Paper, "Our Army Profession", issued by General Raymond T. Odierno in January 2012) an essential prerequisite for an organization to be considered a profession (Odierno, 2012). The level of trust a society has in an institution will determine the professional status of this organization. In other words, the society is the only element that grants an organization and its members the status of a profession.

Building this trust and, most importantly, maintaining it is a long and constant process that an organization should carry out with utmost dedication. The process includes the ability to self-evaluate, provide the society with exclusive services which cannot be performed by any other institution, and uphold high moral and ethical standards prevalent in the society (Odierno, 2012).

Effects of the proposed OCD system should reaffirm the existing trust that the society has in the SAF, build a more competent officer corps, and help establish the relevance of the SAF in the society. The former Minister of Defence of the RS, Ljubica Jelušič, defined the officer corps as the most professional part of the SAF (Jelušič, 1997). The proposed OCD system is intended to provide a more effective and transparent personnel management system in the SAF, which should enable further development of the SAF's most professional part. This should have significant effects on the SAF in the future in the light of fiscal constraints which have already affected almost half of the SAF's budget in the last four years. 
Having professional leadership should enable executing the required tasks in the SAF and meeting the future challenges. It would also allow for the execution of the transformation processes which, among other things, are aimed at reconnecting the SAF with the society. Alternatively, as the current Chief of GS SAF, MG Dobran Božič, stated, "One of the goals of the transformation in the SAF is also the mindset that our military comes from the society and should also give back to the society." (Božič, 2013: 10-11)

The process of establishing the relevance of the SAF in the society is also supported by the proposed OCD system through a clear set of competencies for individual officers at different stages of their career. One of the initial steps of the transformation process is relocating smaller-size units to periphery military installations and thus decentralizing the concentration of units in larger cities. The relocation of certain company-sized elements to smaller military installations requires company commanders to be able to communicate effectively with the local community and the local government, as they are trained to do on deployment. The ability to execute these tasks is part of the proposed OCD system which also encompasses the competencies needed to support the additional steps required for the SAF's transformation process.

Through the transformation process, the SAF also executed several initiatives in the area of civil-military cooperation. This will be made even easier through the intensified dialogue that the relocated units will have with local government representatives, where they will be able to identify the needs of local communities. In this light, the SAF is continuing to provide logistic support to every major sporting and other event in the RS. Identifying the needs of local communities and providing support to major events in the RS requires certain competencies that the proposed OCD system encompasses in the MET.

The transformation process of the SAF will require additional sets of competencies that officers should have in order to meet the goals of the transformation process, maintain the level of trust of the society, and build on the attributes of a professional institution. Only a transparent and competitive OCD system will provide the environment fit to produce such leadership in the SAF that will be able to answer and respond to those demands.

While some changes in the SAF require a two-thirds vote in the Parliament of the RS, the proposed OCD system intentionally avoids those recommendations. This, however, does not preclude the additional changes from further developing the OCD system in order to allow an even more transparent career path for all members of the SAF. The most obvious change in the current legislation is the change in the promotion system in ranks. As discussed in this article, the current promotion system in ranks is based on the promotion in assignments, followed by years in service and, afterwards, the promotion in rank. 
The current system is based on the existing legislation and requires an individual to assume assignments executed in rank that is higher than his or her personal rank. This might work while an individual works in a domestic environment, but is hardly understood by our partners in the international community. It creates unnecessary confusion and, in many cases, hinders the career prospects of an individual in the international community where he or she might be competent to assume certain assignments but cannot do so due to their personal rank. Although the proposed OCD system builds an individual's career with clearly communicated competencies for higher assignments, it does not change the promotion in rank system. Only changes in the existing legislation would allow an individual promotion in rank based on his or her future potential and not on past accomplishments.

The article describes the current operational environment in which the SAF is developing its officer corps. Using the lenses of the future challenges of the SAF, the author recommends an improved OCD system which will produce officers able to lead the SAF to face those challenges. The article discusses the reasons for changing the OCD system and its effects on the current structure of the Officer Corps in the SAF. It also provides recommendations needed to change the current OCD system, which can be made without any changes to the legislation in the defence sector. The proposed OCD system is intentionally built upon the existing legislation and does not require any political decisions for its implementation.

Probably one of the most important things the proposed OCD system requires now is a high level of maturity of an organization and willingness to implement the changes discussed the paper. The responsibility lies with the SAF leadership who are controlling the "human resource systems, which are so vital to the Army being a profession." (Snider, 2012: 30). If they will include those changes in the existing acts and directives within the SAF, then it is the responsibility of the existing officer corps to implement them in all functions of the personnel management system. 


\section{APPENDIX}

\section{TABLE OF PROPOSED COMPETENCIES}

\begin{tabular}{|c|c|c|}
\hline Number & Competency & Description \\
\hline 1. & Emotional intelligence & $\begin{array}{l}\text { An individual maintains relaxed, calm and controlled reactions to } \\
\text { challenging situations, while understanding the ambiguity of an } \\
\text { environment, and with his actions diminishes the ill effects of a } \\
\text { challenging environment. In stressful situations an individual acts } \\
\text { reasonably and effectively and is able to solve problems that occur. }\end{array}$ \\
\hline 2. & $\begin{array}{l}\text { Management of } \\
\text { resources }\end{array}$ & $\begin{array}{l}\text { An individual is prudently using the given resources to accomplish } \\
\text { the task; he or she is aware of the scarce resources and uses them } \\
\text { only when necessary. He or she prevents unnecessary damage } \\
\text { to material, therefore also keeping down the costs of repair or } \\
\text { replacement. }\end{array}$ \\
\hline 3. & $\begin{array}{l}\text { Effective } \\
\text { communication in } \\
\text { Slovenian and at least } \\
\text { one of official NATO } \\
\text { languages }\end{array}$ & $\begin{array}{l}\text { An individual has the ability to express his or her thoughts well, with } \\
\text { exact and clear instructions orally and in written form in Slovenian } \\
\text { and one of the official NATO languages. He or she is also able to } \\
\text { publish articles in the RS Defence System official magazines. }\end{array}$ \\
\hline 4. & $\begin{array}{l}\text { Ability to work and } \\
\text { communicate in } \\
\text { an international } \\
\text { environment }\end{array}$ & $\begin{array}{l}\text { An individual has the ability to communicate in an official NATO } \\
\text { language, and understands other nations' military techniques and } \\
\text { procedures as well as local culture. He or she understands and } \\
\text { respects cultural diversity and uses it to accomplish the coalition } \\
\text { mission. }\end{array}$ \\
\hline 5. & Motivation & $\begin{array}{l}\text { An individual displays the ability to overcome obstacles with } \\
\text { initiative, which is reflected in their attitude, which is also transferred } \\
\text { to their subordinates and soldiers. }\end{array}$ \\
\hline 6. & Responsibility & $\begin{array}{l}\text { An individual is confident in making decisions which will lead to the } \\
\text { accomplishment of a mission or task, and accepts the consequences } \\
\text { of failure or success. When an individual is leading, he or she creates } \\
\text { a shared understanding oriented towards mission accomplishment } \\
\text { and promotes timely execution. }\end{array}$ \\
\hline 7. & Life by SAF values & $\begin{array}{l}\text { An individual respects and works with SAF values: patriotism (an } \\
\text { individual is loyal to the RS and is prepared to work hard for the } \\
\text { good of the SAF and the RS); courage (an individual expresses no } \\
\text { fear while executing demanding and dangerous assignments, and } \\
\text { displays moral courage); loyalty (an individual is prepared to work } \\
\text { hard to contribute to the success of the SAF); selfless service (an } \\
\text { individual executes his tasks anytime and anyplace necessary, his } \\
\text { or her goals are subordinated to the goals of the SAF); honour (an } \\
\text { individual is a proud member of the SAF and shows that with his } \\
\text { demeanour in public life); esprit de corps (an individual respects } \\
\text { other members of the organization, helps them execute their tasks } \\
\text { and invests in personal relationships with other members of the SAF) }\end{array}$ \\
\hline 8. & Accuracy & $\begin{array}{l}\text { An individual concentrates on accurate execution of his or her } \\
\text { tasks and avoids mistakes. While working with numbers, maps and } \\
\text { drawings, the individual is careful and thorough. }\end{array}$ \\
\hline 9. & Reliability & $\begin{array}{l}\text { An individual executes tasks in a timely manner and demonstrates a } \\
\text { sense of duty and commitment. }\end{array}$ \\
\hline 10. & Initiative & An individual always looks for new approaches to solving issues. \\
\hline 11. & Physical fitness & $\begin{array}{l}\text { An individual demonstrates satisfactory physical fitness through } \\
\text { various evaluated events such as: Army Physical Fitness Test, } \\
\text { prescribed marches, and mountain climbing. }\end{array}$ \\
\hline
\end{tabular}




\begin{tabular}{|c|c|c|}
\hline Number & Competency & Description \\
\hline 12. & Tactical proficiency & $\begin{array}{l}\text { An individual is proficient in individual tactical skills, as well as in } \\
\text { effectively employing his or her unit and weapon systems in decisive } \\
\text { actions through the ability to comprehend the higher intent, develop } \\
\text { a plan, effectively communicate the plan to subordinates, and } \\
\text { effectively exercise control throughout execution. }\end{array}$ \\
\hline 13. & $\begin{array}{l}\text { Subordinate } \\
\text { development }\end{array}$ & $\begin{array}{l}\text { An individual is a steward of his or her profession and strives to } \\
\text { develop subordinates and help peers in understanding their role and } \\
\text { tasks and the military profession in general. }\end{array}$ \\
\hline 14. & $\begin{array}{l}\text { Professional } \\
\text { effectiveness }\end{array}$ & $\begin{array}{l}\text { An individual carries out the full range of tasks effectively, shows } \\
\text { clear understanding of the professional environment, and displays } \\
\text { interest in wider aspects of the defence and current affairs. He or she } \\
\text { also seeks to enhance professional knowledge and understanding } \\
\text { of new technology and other military developments in Slovenia and } \\
\text { other countries. }\end{array}$ \\
\hline 15. & Leadership & $\begin{array}{l}\text { An individual projects a strong persona and character to motivate } \\
\text { subordinates to do what is required of them, and promotes a } \\
\text { positive sense of purpose and direction. The individual also inspires, } \\
\text { influences, directs and supports others in both routine activities and } \\
\text { under stress; he or she instils self-esteem, team spirit and unity of } \\
\text { effort through developing a shared understanding. He or she creates } \\
\text { early momentum and success, leads with firmness and fairness, } \\
\text { demonstrates responsibility for those under their command, sets an } \\
\text { example consistent with SAF values and standards, and motivates } \\
\text { others to embrace change when change is required. }\end{array}$ \\
\hline 16. & Embrace ambiguity & $\begin{array}{l}\text { An individual is aware of unpredictable environments, friction on } \\
\text { the battlefield and other uncertainties. He or she executes positive } \\
\text { control over subordinates and communicates with mission-type } \\
\text { orders to allow the initiative of subordinates. }\end{array}$ \\
\hline 17. & Analytical skills & $\begin{array}{l}\text { An individual is able to recognize certain characteristics and causes } \\
\text { of diverse challenges. He or she uses a logical and systematic } \\
\text { approach to problem solving. }\end{array}$ \\
\hline 18. & Interdisciplinary skills & $\begin{array}{l}\text { An individual has the ability to connect knowledge from different } \\
\text { areas of expertise and is able to work in other fields when necessary. }\end{array}$ \\
\hline 19. & MDMP proficiency & $\begin{array}{l}\text { An individual understands and uses the methods and techniques of } \\
\text { the MDMP process; he or she understands the value of cooperation } \\
\text { in the process. Their products are in accordance with the doctrine } \\
\text { and they are able to present them in a concise and accurate manner. }\end{array}$ \\
\hline 20. & Organizational skills & $\begin{array}{l}\text { An individual is organized and able to use time effectively, and } \\
\text { organizes the work for subordinates. }\end{array}$ \\
\hline 21. & $\begin{array}{l}\text { Mission Command } \\
\text { systems proficiency }\end{array}$ & $\begin{array}{l}\text { An individual is able to use the Mission Command system while } \\
\text { analyzing and presenting products from higher systems and } \\
\text { developing their own. }\end{array}$ \\
\hline
\end{tabular}




\section{Bibliography}

1. Army Doctrine Publication (ADP) 6-22, Mission Command. Washington, DC: Government Printing Office, 2012.

2. Bozic, D., 2013. Po preoblikovanju bo SV bolj vključena v prostor (The SAF will be more connected with the society after the reorganization), Slovenian Armed Forces Magazine, year 2013, No. 5 (May 2013).

3. Centre for Public Opinion Research. Politbarometer 1/2013 (Political Barometer 1/2013). Centre for Public Opinion Research, Ljubljana, 2013.

4. Government of the Republic of Slovenia, 2013. Srednjerocni obrambni program Republike Slovenije (Midterm Defence Programme of the Republic of Slovenia). Ljubljana, RS: The Government of the Republic of Slovenia, 2013.

5. Jelušič, L., Kronja-Stanic, N., 1997. Legitimnost Sodobnega Vojaštva (Legitimacy of Modern Soldiery). Ljubljana: Faculty of Social Sciences, Knjižna zbirka Teorija in Praksa (Book series Theory and Practice).

6. Kohont, A., Naglič, M., 2008. Analiza kompetenc v Slovenski vojski (An Analysis of Competency in the Slovenian Armed Forces (SAF), Slovenian Armed Forces Bulletin 10, No. 1 (May 2008), pp. 159-184.

7. Kotnik-Dvojmoč, I., 2008. Kakšen naj bo sodobni častnik Slovenske vojske in kako do njega (A Modern Officer of the Slovenian Armed Forces: Their Characteristics and Formation). Slovenian Armed Forces Bulletin 10, No. 1 (May 2008), pp. 75-96.

8. Matthews, L. J., Snider, D. M., 2005. The Future of the Army Profession. Rev. and expanded, $2^{\text {nd }}$ ed. Boston, MA: McGraw-Hill.

9. Merriam-Webster Dictionary, 2013. http://www.merriam-webster.com/dictionary/officer (accessed April 25, 2013).

10. Ministry of Defence of the Republic of Slovenia, 2004. Obvezne usmeritve za sistem kariernih poti za pripadnike stalne sestave SV (Guidance for developing career models in the SAF). Ljubljana, RS: Ministry of Defence, 2004.

11. National Assembly of the Republic of Slovenia, 2013. Strategija o nacionalni varnosti Republike Slovenije (The National Security Strategy of the Republic of Slovenia). Ljubljana.

12. Obvezne usmeritve za vodenje kariernih poti vojaških oseb, 2013 (Guidance for managing career paths for military personnel). Ljubljana, RS: Ministry of Defence, 2013.

13. Odierno, R. T., 2012. The United States Army: A Noble Calling, a Trusted Profession. White Paper - Our Army Profession. January, 2012. http://cape.army.mil/ CompanyCommander/Student $\% 20$ Handouts/Our\%20Army\%20Profession_Final\%20 Working\%20Draft_24MAR12.pdf (accessed October 24, 2013).

14. Pesec, M., 2013. Doktrina vojaskega izobrazevanja in usposabljanja (Training and Education Doctrine). Maribor: PDRIU.

15. Pravilnik o štipendiranju v Slovenski vojski, 2008. (Regulation for Scholarship in the $S A F)$, National Assembly of the Republic of Slovenia. Ljubljana, Uradni list RS (Official Gazette of the RS).

16. Snider, D. M., 2012. Once again, the challenge to the U.S. Army during a defence reduction: To remain a military profession. Strategic Studies Institute, Carlisle Barracks, $P A$.

17. Stefanic, T., 2010. Dejavniki razvoja kariere (Factors of Career Development). Master's Thesis, University of Ljubljana.

18. Tomazic, E., 2013. Merite učinke kadrovske funkcije, da jo boste LAHKO upravljali. (Manage the effects of the personnel management function, so you will be ABLE to use it). Finance, July 20, 2013. http://www.finance.si/8343795/Merite-u\%C4\%8Dinke-kadrovskefunkcije-da-jo-boste-LAHKO-upravljali (accessed July 20, 2013).

19. U.K. Ministry of Defence, U.K. Army. Officers Career Development Handbook. London, UK, Army code 64257, 2005. 
20. U.S. Department of the Army. Department of the Army Pamphlet 600-3, Commissioned Officer Professional Development and Career Management. Washington, DC: Government Printing Office, 2010.

21. Uredba o činih in poviševanjih v Slovenski vojski, 2002. (Regulation on ranks and promotions in the SAF), National Assembly of the Republic of Slovenia. Ljubljana, Uradni list RS (Official Gazette of the RS).

22. Zakon o obrambi (Defence Act), 2004. National Assembly of the Republic of Slovenia. Ljubljana, Uradni list RS (Official Gazette of the RS).

23. Zakon o službi v Slovenski vojski (Service in the Slovenian Armed Forces Act), National Assembly of the Republic of Slovenia. Ljubljana, Uradni list RS (Official Gazette of the $R S)$. 